\title{
The Role of English Ability in Income in Kathmandu, Nepal Front-line Ecotourism Employees
}

\author{
Jeffrey Stewart Morrow, Ph.D. \\ Faculty of Environmental and Symbiotic Sciences, Department of Environmental Resources \\ Prefectural University of Kumamoto, Japan \\ morejeff@gmail.com
}

\begin{abstract}
The Kathmandu, Nepal ecotourism industry (NETI) has been remarkable for decades, and this growth has seen a $71 \%$ increase in tourism GDP since 2000. Travelers wishing to visit Kathmandu as well as engage in ecotourism activities mostly come from inner circle and outer circle countries and use English for tourism purposes. This requires ecotourism employees to have excellent commands of English; however, English communication data has been lacking in Nepal. To fill this gap the author conduced a preliminary survey in ecotourism businesses around Kathmandu in order to gather background socioeconomic, education, English education, and employment data. English communication ability was also measured in order to statistically calculate with other variables, such as income and years of schooling, to verify whether correlations existed. Results found positive correlations when English ability was used as a dependent variable, and also when income was used as a dependent variable. These results suggest that the association between income and English ability is highly significant.
\end{abstract}

Keywords: English communication ability, English ability and income, employment, income, front-line, employees, English education

\section{INTRODUCTION}

Since the 1960's, international travelers have been visiting the country of Nepal, gateway to the Himalaya Mountains and Tibet, to participate in ecotourism activities such as hiking and trekking. It goes without saying that the economic impact from international travelers has been large. According to the government of Nepal, Travelers have increased from 254,885 in 1990 to 790,118 in 2014, a growth rate of $67 \%$. Many tourists are from inner circle ${ }^{1}$ countries, where English is spoken as a native language; in fact, in 2014, the largest number of travelers was from India, followed by China ${ }^{2}$, the U.S. (an inner circle country), Sri Lanka, and the U.K. (also an inner circle country). This influx has bolstered the need for English speaking guides for climbers and trekkers as well as for excellent communication in employees of tourism related businesses such as souvenir shops, restaurants, guesthouses, and hotels. The author's assumption is that all factors relating to English background, including years and hours of English education and expenditure for English study will lead to obtaining higher salaries and better employment, especially among guides and guide agencies due to their long work relationships with international travelers. While there is ample data on tourist influx and trekking in the area, data on English education and English communication ability in Nepal has been lacking. Therefore, the goal of the author was to conduct a preliminary survey in order to: 1) collect background socioeconomic and education data of tourism employees, 2) to assess individual employees' English communication ability, and 3) to use the data in calculations with statistical measures to check correlations to determine if the assumption mentioned above has validity.

To this end, a survey of five ecotourism related businesses was conducted in order to obtain a precursory view of whether or not higher English ability levels can help employees obtain better employment and higher incomes in NETI. In order to do this, the author and research assistant gathered background socioeconomic and educational data, as well as measured employees' English

\footnotetext{
${ }^{1}$ Kachru's concentric circles of English (1985): inner circle, where English is a native language, outer circle, where English is used a lingua franca and in business/politics; and expanding circle, which includes the remainder of countries

${ }^{2}$ Even thought China cannot be considered an inner circle country, the author assumes that English would still most likely be used in day-to-day communication for tourism purposes.
} 
ability in fact-to-face interviews. This paper will share the results of the study conducted in March 2016 in downtown Kathmandu. English ability was used as a variable for examining for determining its role in employment and income; however, an accurate assessment scale of measuring English ability was lacking in literature. To fill this gap, the author created a numeric system for measuring English loosely based on the Common European Framework of Reference for Languages (CEFR). The CEFR contains levels on a concrete scale, which is quite clear (Table 1). The author emulated this feature, but created a more numeric scale, and also included levels from (0) for those with no ability whatsoever, to (5) for those with advanced ability. In this way, the scale can be quantified and calculated accurately to verify its importance with a large population. The author's assessment can be found in Table 2.

Table1. Cefr Reference Levels

\begin{tabular}{|l|l|}
\hline A1 & Breakthrough or beginner - can understand familiar everyday expressions, can introduce self \\
A2 & Way stage or elementary - can understand and use expressions within immediate relevance \\
B1 & Threshold or pre-intermediate - can understand main points and deal with traveling \\
B2 & Vantage or intermediate - can understand and produce ideas on concrete and abstract topics \\
C1 & Effective operational proficiency - can get implicit meaning, can use language flexibly \\
C2 & Mastery or advanced - can understand everything, can express spontaneously and fluently \\
\hline
\end{tabular}

Source. Adapted from CEFR, Council of Europe for Language Education, 2001.

Table2. The Author's Variation of English Ability Assessment

\begin{tabular}{|l|l|}
\hline $\mathbf{0}$ & No or little ability - can't communicate at all \\
$\mathbf{1}$ & Beginner - can only understand and use familiar everyday expressions \\
$\mathbf{2}$ & High Beginner - can understand and use expressions within everyday relevance \\
$\mathbf{3}$ & Intermediate - can understand many things, can produce but with many mistakes \\
$\mathbf{4}$ & High Intermediate - can understand and produce ideas but with lower confidence \\
$\mathbf{5}$ & Advanced - can understand everything and produce fluently and confidently \\
\hline
\end{tabular}

Source. Author, 2013

Section two reviews related literature. Section three explains the method and instruments. Section four offers socio-economic demographic information of Nepal ecotourism. In section five, survey results are given, and section six discusses findings. Section seven concludes.

\section{LiteratURE REVIEW}

Since the 1970's, researchers have been investigating the effect of education on future employment and income. Becker (1964) found high returns to having more human capital attainments. Mincer (1974) found high returns for those with more education and experience. A few studies have focused on English proficiency in English proficiency business in developing countries. (Casale and Posel, 2010) found high premiums to those with college degrees and who spoke English in South Africa where English is the lingua franca of business and politics. Economic returns to English ability, with labor market experience, in immigrants to inner circle countries have been investigated. Bellante \& Kogut (1998) found that English proficiency was important in regards to hourly wages; returns can increase $26 \%$ by additional year in the U.S. Kim (2003) explored English and income in male Chinese and Mexican immigrants to the U.S. Results found that Chinese immigrants, who are better educated with a better English ability earn more and are in managerial positions. As a result, marginal impact for one additional year of schooling is more severe in Chinese workers. Results found that lack of English ability with regards to earnings in immigrants is substantial. While not specifically English and not tourism, DiPaolo \& Tansel (2015) have discovered high economic value of skills in a foreign language in Turkey, which has international trade, high tourism arrivals, and many FDI projects. English is evident in most of the citizens there and is usually known by white-collar employees who acquire most English in schools (79\%); some learn with a teacher or privately. Empirical test returns to English proficiency are positive and increasing between 20 and $46 \%$.

\section{Method And InSTRument}

The author and research assistant conducted a survey in the tourism industry in downtown Kathmandu, Nepal. The survey objective was to gather data on background social and education situation of NETI employees for the purpose of investigating the effect of English communication ability on employment and income of ecotourism employees. 


\subsection{Survey Location}

The survey took part from March 4-March 6, 2016 in several tourist areas of Kathmandu: Patan, Durbar Square, Boudanath Stupa, Pashuputinath Temple, and Kopan Monastery. The locations were chosen randomly before the survey. The author received permission from each location before proceeding with the interviews. The author wished to examine only locations with an international clientele. For that reason, local businesses were excluded. The author wished to interview employees only, so owners and managers were also excluded.

\subsection{Sample}

A two stage sampling style was used in this survey. First, the businesses to be included in the survey were chosen from among the total businesses. Souvenir shops, restaurants, hotels, and travel agencies, were chosen because they were undisputedly ecotourism businesses and stand out as such. Exact population was unknown, so the author and assistant manually counted the businesses and tabulated them. The sample size was then determined using a 95\% confidence level and a confidence level of 11. The businesses to be under study were then chosen randomly. Next, the participants from each business to be interviewed in face-to-face interviews were chosen randomly from this group. All members agreed to participate in face-to-face interviews for the study. The total sample strata were 75 employees of the NETI of Kathmandu. The strata for each location were: souvenir shops, 39; restaurants, 13; hotels, 15; and travel agencies, 8 . This was determined to be an appropriate sample size for a preliminary survey. All participants agreed to take part in the survey.

\subsection{Data Collection}

In order to collect data, the author hired an assistant with advanced English ability and knowledge of the ecotourism industry. The assistant had also worked with volunteers for years in downtown Kathmandu area, and also in the outlying rural areas of Nepal. Before conducting interviews, the author and assistant contacted each business with which to have interviews. The surveys were conducted all in English; however, when problems arose, the assistant translated information to the Nepali mother tongue or indigenous tongue.

\section{DEMOgRaPhics}

Table 3 contains demographic information from the survey. The majority of the labor force (35\%) was in the 20-year age bracket. Of the total, $65 \%$ of NETI employees were male $(65 \%) ; 35 \%$ was female. In addition, $56 \%$ of the participants were from provinces other that Kathmandu. This is somewhat surprising given the fact that Nepal has a plethora of ecotourism activities in other provinces, and usually migration to the capital occurs with less economic stability in a particular area. Of the total, 64\% were married, and of those, 57\% had children; 53\% lived with husbands/wives and children, while $32 \%$ lived with mothers and fathers. Most NETI employees in Kathmandu are married, have children, and live with husband and wives. This can only be indicative of NETI stability in Kathmandu from years of NETI activity and millions of international visitors who have crossed its borders since the 1950's.

Table3. General Demographics of Ecotourism Labor Force, Kathmandu, 2016 (Number)

\begin{tabular}{|c|c|c|c|c|c|}
\hline \multicolumn{2}{|l|}{ Item } & Souvenir Shops & Restaurants & Hotels & Travel Agencies \\
\hline \multirow[t]{5}{*}{ Age } & 10-19 & 4 & 0 & 0 & 0 \\
\hline & $20-29$ & 12 & 3 & 10 & 1 \\
\hline & 30-39 & 10 & 7 & 2 & 3 \\
\hline & $40-49$ & 9 & 3 & 2 & 4 \\
\hline & $50+$ & 4 & 0 & 1 & 0 \\
\hline \multicolumn{2}{|l|}{ Total } & 39 & 13 & 15 & 8 \\
\hline \multirow[t]{2}{*}{ Sex } & Male & 22 & 12 & 8 & 7 \\
\hline & Female & 17 & 1 & 7 & 1 \\
\hline \multicolumn{2}{|l|}{ Total } & 39 & 13 & 15 & 8 \\
\hline \multirow[t]{3}{*}{ Province } & Kathmandu & 8 & 5 & 8 & 3 \\
\hline & Patan & 7 & 1 & 1 & 0 \\
\hline & Other & 24 & 7 & 6 & 5 \\
\hline \multicolumn{2}{|l|}{ Total } & 39 & 13 & 15 & 8 \\
\hline \multirow[t]{2}{*}{ Marital } & Married & 25 & 9 & 8 & 6 \\
\hline & Single & 14 & 4 & 7 & 2 \\
\hline
\end{tabular}


Jeffrey Stewart Morrow, Ph.D.

\begin{tabular}{|c|c|c|c|c|c|}
\hline \multicolumn{2}{|l|}{ Total } & 39 & 13 & 15 & 8 \\
\hline \multirow[t]{2}{*}{ Children } & Yes & 23 & 8 & 9 & 3 \\
\hline & No & 16 & 5 & 6 & 5 \\
\hline \multicolumn{2}{|l|}{ Total } & 39 & 13 & 15 & 8 \\
\hline \multirow[t]{4}{*}{ Living } & Alone & 2 & 1 & 1 & 2 \\
\hline & W/mthr,fthr & 13 & 4 & 6 & 1 \\
\hline & W/hus,wife & 24 & 8 & 8 & 0 \\
\hline & Other & 0 & 0 & 0 & 0 \\
\hline \multicolumn{2}{|l|}{ Total } & 39 & 13 & 15 & 8 \\
\hline \multirow[t]{4}{*}{ Schooling } & 6 years & 4 & 2 & 0 & 1 \\
\hline & 9 years & 9 & 4 & 1 & 1 \\
\hline & 12 years & 16 & 3 & 9 & 4 \\
\hline & 16 years & 8 & 4 & 5 & 2 \\
\hline \multicolumn{2}{|l|}{ Total } & 39 & 13 & 15 & 8 \\
\hline$n=75$ & & & & & \\
\hline
\end{tabular}

Source. Derived from Survey Data, 2016

Another indicative factor of economic stability in NETI is the fact that $85 \%$ of employees have graduated from high school, and $25 \%$ have finished college or university in Nepal. Along with high school and college general education, English education is important in primary and secondary schooling. Nepal is unique in that schools allow students to choose between two tracks: a normal track, and an English "base" track in which they study all subjects in English. Most of these students in the English track, as one can imagine, become fluent in English and have good commands of listening, speaking, reading, and writing; however may lack the natural communicative competence of native speakers. The author and research assistant encountered several participants who had chosen the English "base" track, and discovered that most of these participants worked at well-paying jobs in hotels or tour guide services, probably due to their higher English skill level, and received a higher remuneration as a result.

\section{Statistical Results}

\section{Quantitative Results}

The paper will now offer statistical results from the survey situation. The results were analyzed using simple statistical analysis. The section will share the mean, SD, and median in these locations: souvenir shops, restaurants, hotels, and travel agencies. The variables along with abbreviations used were: English ability (ENL), income (INC), total years of schooling (TYS), years of English education (YEE), hours of English education (HEE), and monthly expenditure (ME), and working hours per week (WH). The order of businesses was chosen based on an ascending level of English ability.

Table4. Mean Values of Kathmandu NETI (in USD)**

\begin{tabular}{|l|c|c|c|c|c|c|c|}
\hline Location & \multicolumn{7}{|c|}{ Variable } \\
\hline & ENL* & INC** & TYS & YEE & HEE & ME** & WH \\
\hline SS & 3.07 & 133.80 & 11.46 & 9.83 & 8.59 & 133.80 & 58 \\
\hline RT & 3.48 & 163.87 & 11.46 & 9.46 & 11.76 & 188.00 & 70 \\
\hline HL & 3.52 & 378.21 & 14.27 & 12.13 & 21.26 & 686.54 & 55 \\
\hline TA & 3.84 & 256.45 & 13.69 & 11.63 & 11.56 & 142.97 & 58 \\
\hline
\end{tabular}

Source. Calculated using survey data, 2016. *ENL (English level), INC (income), TYS (total years of schooling), YEE (years of English education), HEE (hours of English education), ME (monthly expenditure), WH (working hours per week). **107.15 Rupee $=1$ USD (exchange rate as of 7/6/2016) http://fxexhcangerate.com

Table 4 contains the mean values from the 2016 survey. The mean values show an ascending correspondence between income, total years of schooling, years of English education, hours of English education, and monthly overall expenditure in this order: souvenir shops, restaurants, travel agencies, and hotels. The variables for $\mathrm{WH}$ show that travel agencies, second from highest on every other variable, actually worked the most hours. Similarly, ENL values also show that travel agency employees, second from highest on all other variables, actually had the highest ENL. The reason for these differences in mean values is most likely because mean is sensitive to the presence of outliers. However, it can be discerned that, generally, the more total years of schooling, more years and hours 
The Role of English Ability in Income in Kathmandu, Nepal Front-line Ecotourism Employees

of English education, and the more monthly expenditure one has to study English, the more income one can earn.

Table5. SD Values of Kathmandu NETI

\begin{tabular}{|l|c|c|c|c|c|c|c|}
\hline Business & \multicolumn{7}{|c|}{ Variable } \\
\hline & ENL & INC & TYS & YEE & HEE & ME & WH \\
\hline SS & 1.04 & 72.05 & 4.16 & 5.10 & 8.83 & 72.05 & 19.28 \\
\hline RT & 0.88 & 65.99 & 3.53 & 1.13 & 8.23 & 241.92 & 15.35 \\
\hline HL & 0.76 & 921.57 & 2.75 & 3.68 & 15.13 & 2374.02 & 15.89 \\
\hline TA & 0.70 & 176.59 & 4.16 & 5.10 & 8.83 & 37.65 & 14.31 \\
\hline
\end{tabular}

Source. Calculated Using Survey Data, 2016

Table 5 displays SD values. SD values show quite wide dispersion in the variables of INC, ME, and WH. This is to perhaps be expected because these are the variables containing the most outliers. Other variables, such as TYS (in souvenir shops and travel agencies), YEE (in souvenir shops and travel agencies), and HEE (in all businesses) also exhibited a large dispersion due to outliers. In order to alleviate the outlier problem, the author used median values in the analysis because median is less sensitive to outliers.

Table6. Median Values of Kathmandu NETI

\begin{tabular}{|l|c|c|c|c|c|c|c|}
\hline Business & \multicolumn{7}{|c|}{ Variable } \\
\hline & ENL & INC & TYS & YEE & HEE & ME & WH \\
\hline SS & 3 & 115.78 & 12 & 11 & 5.5 & 115.78 & 54 \\
\hline RT & 3.5 & 163.87 & 12 & 8 & 6 & 102 & 54 \\
\hline HL & 3.5 & 171.35 & 15 & 12 & 25 & 46.31 & 48 \\
\hline TA & 4.25 & 185.25 & 15 & 12.5 & 6 & 141.23 & 51 \\
\hline
\end{tabular}

Source. Calculated Using Survey Data, 2016

Table 6 contains median values; as the table shows, most values more thoroughly corresponded on an ascending scale probably most similar to the actual values. The author's assumption at the outset was that higher English levels help employees receive better employment and income in Kathmandu tourism. Upon examining Table 6, it is evident that those with: a lower English level, fewer total years of schooling, fewer of English study per week earn less income than those with higher English levels, more total years of schooling, and more hours of English study per week. The study also examined mean, SD, and median values in the 7 variables mentioned previously: ENL, INC, total years of schooling, years of English education, hours of English education, monthly expenditure, and working hours per week for the ETA employees combined (Table 7).

Table7. Mean, SD, Median Values of Kathmandu NETI (Combined, in USD)**

\begin{tabular}{|l|c|c|c|}
\hline Variable & \multicolumn{3}{|c|}{ Measure } \\
\hline & Mean & SD & Median \\
\hline ENL $^{*}$ & 3.31 & 1.04 & 171 \\
\hline INC** & 200.99 & 419.90 & 12 \\
\hline TYS & 12.26 & 3.94 & 10.5 \\
\hline YEE & 10.42 & 4.09 & 6 \\
\hline HEE & 11.99 & 11.64 & 53 \\
\hline ME** & 142 & 162.35 & 54 \\
\hline WH & 59 & 19.83 & \\
\hline
\end{tabular}

Source. Calculated using survey data, 2016. *ENL (English level), INC (income), TYS (total years of schooling), YEE (years of English education), HEE (hours of English education), ME (monthly expenditure), WH (working hours per week). **107.15 Rupee $=1$ USD (exchange rate as of 7/6/2016) http://fxexhcangerate.com

In this table, the mean ENL was 3.31, or midway between low intermediate and high intermediate; the SD (1.04) showed that data were relatively close to the central line, as is evident in the median values. INC mean was 200.99, while the SD showed much dispersion; median values give a better idea that income was around USD171. TYS values were around 12. YEE were 101/2. HEE on the other hand appear to be 6 . Monthly expenditure was around USD93 judging be the median value. WH's were around 54 or so. 
Since there were many outliers in the data, the sample was small, and the background was not fully known, it was felt that the data was not fitting for Pearson's R correlation. For this reason, the Spearman's Rho non-parametric correlation test was used in data analysis. Four variables were used in Rho calculations along with income to show significance in two analyses, using the strata calculated as a whole.

1) The variables in the first analysis were: Income (INC) as the dependent variable, and English communication level (ENL), total years of schooling (TYS), years of English education (YEE), hours of English education (HEE), monthly expenditure (ME), working years (WY), and working hours per week (WH) as the independent variables.

2) In the second analysis, English level (ENL) was used as the dependent variable, and income (INC), total years of schooling (TYS), years of English education (YEE), hours of English education (HEE), monthly expenditure (ME), working years (WY), and working hours per week (WH) were used as independent variables.

\section{Analysis 1}

In the first analysis (Table 8), the strata $(\mathrm{N}=75)$ were calculated together as a whole using INC as the dependent variable, and others as independent variables. The English level had an R-value of 0.28 and the two-tailed P-value was 0.01. Therefore the association between income and English level is statistically significant. Total years of schooling had an R-value of 0.11 and the two-tailed P test value was 0.32. Therefore the relationship between income and total years of schooling variables is not significant. Years of English education had an R-value of -0.07 and the two-tailed P-value was 0.49; therefore this association is not considered significant. Hours of English education R-value was 0.03 and the two-tailed $\mathrm{P}$ value was 0.76 . Therefore, this association is not significant. Monthly English expenditure R-value was -0.02 and the two-tailed P-value was 0.81 .Therefore the association between income and monthly English expenditure is not significant. Working years variable had an R-value of 0.35 and the two-tailed P-value was 0.001. Therefore the association between income and working years is considered significant. Working hours per week had an R-value of 0.26 and the two-tailed Pvalue was 0.02 . Therefore the association between income and working hours is considered significant.

Table8. Significance of Variables in Spearman's R (Analysis 1)

\begin{tabular}{|l|l|l|}
\hline Variable combination & Significant & Not significant \\
\hline INC/ENL & O & \\
\hline INC/TYS & & $\mathrm{O}$ \\
\hline INC/YEE & & $\mathrm{O}$ \\
\hline INC/HEE & & $\mathrm{O}$ \\
\hline INC/ME & & $\mathrm{O}$ \\
\hline INC/WY & $\mathrm{O}$ & \\
\hline INC/WH & $\mathrm{O}$ & \\
\hline
\end{tabular}

Source. Calculated Using Survey Data, 2016

\section{Analysis 2}

In the second analysis (Table 9), the strata were calculated together as a whole using ENL as the dependent variable and the others as independent variables. Income had an R-value of 0.28 and the two-tailed $\mathrm{P}$ value was .01. Therefore, the association between English level and income is considered significant. The total years of schooling variable R-value was 0.37 and the two-tailed P-value was 0.0007. Therefore the association between English level and totally years of schooling is significant. Years of English education R-value was 0.50 and the two-tailed P-value was 0; therefore this association is considered significant. Hours of English education R-value is 0.37, and the two-tailed $\mathrm{P}$-value was 0.001. Therefore the association between years of English education and hours of English education is considered significant. Monthly English expenditure R-value was 0.08 and the two-tailed $\mathrm{P}$-value is 0.48 . Therefore, the association between English level and monthly English expenditure is not significant. Working year R-value was 0.05 and the two-tailed P-value was 0.63 ; therefore this association is not considered significant. Working hours per week R-value is -0.20 and the two-tailed $\mathrm{P}$-value was 0.07. Therefore the association between English level and working hours per week is not significant. 
Table9. Significance of Variables in Spearman's $R$ (Analysis 2)

\begin{tabular}{|l|l|l|}
\hline Variable combination & Significant & Not significant \\
\hline ENL/INC & O & \\
\hline TYS/INC & O & \\
\hline YEE/INC & O & \\
\hline HEE/INC & O & \\
\hline ME/INC & & $\mathrm{O}$ \\
\hline WY/INC & & $\mathrm{O}$ \\
\hline WH/INC & & $\mathrm{O}$ \\
\hline
\end{tabular}

Source. Calculated Using Survey Data, 2016

\section{Qualitative Results}

This study has examined English communication ability and English background in calculations with other variables, and has found statistical significance in many cases. These findings verify that the need for English ability is paramount for employment and income in NETI. However, quantitative surveys are not enough to examine the entire social situation in Kathmandu. For that reason, the questionnaire contained qualitative questions, which helped the author discover more about the English learning and usage environment in NETI. It is hoped that these questions could gather more concrete information to be used for creating effective English programs for ecotourism communication. The answers were on a numeric scale or obtained using a Likert scale where necessary. The questions and answer configuration will now be shared. 1) Did your English ability help you obtain your job in ecotourism? 2) Is your income better with English ability? 3) Do you think your English ability will help you get a better job in the future? 4) What is the percentage of your English understanding? 5) Do you study English now? 6) What is the corresponding use of English at your place of employment? 7) How often do native speakers visit your places of employment? 8) What would you consider your own English ability?

Results show that in response to the first question, 72 participants (96\%) felt their English ability helped them obtain their present jobs in the ecotourism industry in Kathmandu. Three people (4\%) responded that it did not; 0 were unsure. Of the total, 55 participants $(73 \%)$ responded that their income was better with higher English ability, while 13 participants $(17 \%)$ responded that it was not better, and 7 people $(9 \%)$ reported that they were unsure. When asked if they think English will help them obtain a better job in the future, 64 participants $(85 \%)$ responded that it would; $6(8 \%)$ responded that it would not; $5(6 \%)$ responded that they were unsure. Two of the participants $(2 \%)$ responded that they had a $0 \%$ level of understanding; 1 (1\%) responded a $10 \%$ level; $13(17 \%)$ responded a 25\%; $23(30 \%)$ responded a $50 \%$ level of understanding; $30(40 \%)$ responded a $75 \%$; and $6(8 \%)$ responded a $100 \%$ level of understanding. When asked if they continue to study English presently, 29 participants (38\%) responded, yes, while $46(61 \%)$ responded, no. As for the corresponding use of English at their places of employment, 5 participants $(6 \%)$ responded they can use just English words; 12 (16\%) responded they can use short sentences; 24 (32\%) could explain in more detail, but with little confidence; 23 (30\%) could explain in more detail with more confidence; and $11(14 \%)$ responded they could explain things 100\%. Of the total, 68 participants (90\%) stated that native speakers visited their places of employment every day, and 7 (9\%) responded that native speakers visited 3 days per week. When asked to rate their own English ability level on a 5 point scale of 1 (low beginner) to 5 (advanced), 9 participants (12\%) responded that they felt they had a level 1 , or low beginning level of English; 9 (12\%) reported that they have a level 2 or high beginning level; 26 participants (34\%) responded that they had a level 3 or low intermediate level; 29 participants (38\%) felt that they had a level 4, or high intermediate level; and $2(2 \%)$ responded that they had a level 5, or advanced level of English ability.

\section{DisCUSSION}

In the quantitative results, the mean values of businesses separately (Table 4) show that the variables working hours per week (WH) and English level (ENL) did not correspond like the other variables in the table; that is, they did not fit on a corresponding ascending scale. There could be several reasons for this. One reason could be that NETI employees perhaps work many overtime hours per week in communication with international travelers, international travel agencies, and airlines in different time zones around the world. Thus, they are required to work more hours than their counterparts. In 
addition, many travel agencies guide hiking and trekking groups throughout the Himalayas and in that case, too, must spend overtime hours guiding, preparing food, and preparing bedding for their guests. Similar reasons for their better English level were found. Travel agents spend time in complex communication while making reservations and tour planning, and guides spend more hours communicating safety and trekking information to their guests, making their English communication levels higher over time. In addition, the mean WH of restaurant staff is extremely high, but this is probably due to the presence of outliers. It also appears in the mean table that those with more years of English education in addition to a higher monthly expenditure (with some money probably going to English study) earn more income as well. This could be due to the fact that they put extra time and money into learning about the ecotourism industry in preparation for their jobs. The exception here are hotels, in which mean values are extremely high, yet median values are the lowest. The reason for this could be that hotels (especially 4 and 5 star) require their employees to be well versed in communication and have excellent English communication skills upon entering the job market. For this reason, employees and families spend money to obtain hospitality education and training first, and hence monthly expenditures are low as there is less need to pay for English study. Median values probably reflect the situation more accurately as they are not sensitive to outliers. In the combined table (Table 7), mean ENL values are quite lower than expected, at 3.5; the author assumed that NETI employees of Kathmandu were better skilled at English communication. Nonetheless, research shows that those with a high intermediate level of 3.5 can earn an income of about USD170-USD200, at least in this data. This amount is actually quite relevant in the NETI.

The Spearman's Rho analysis shows that there are significant as well as insignificant values. Interestingly, in analysis 1, the association between INC and ENL is statistically significant, while INC with TYS, YEE, and HEE were not significant. The author assumed that most English background variables would have significant correlations with income; but this was not the case. However, ENL is a combination of years of English education and hours of English education, so it makes sense that all of these variables work in combination. At any rate, this analysis verifies the importance of ENL in achieving higher INC because of the positive correlation. INC with WY and WH are significant, and this makes sense in that these factors are closely related to working and therefore to INC. In analysis 2, the correlations of ENL with TYS, YEE, and HEE are statistically significant because they are involved with education and learning English. The correlation of ENL with ME, ENL with WY, and ENL with WH are not significant, however. This makes sense in that these variables have nothing to do with ENL. Interestingly, the correlation for ENL and INC is also considered significant for analysis 2, further verifying the role of English ability in employment and especially income.

As for the qualitative results, the fact that $96 \%$ of employees felt that their English ability helped them obtain their present position is important because this gives them hope for the future. It is also positive to note that $73 \%$ felt they were able to receive a higher income with English, and $85 \%$ felt that they would be able to find better employment in the future. A fact that surprised the author was that $30 \%$ felt they only had a 50\% level of understanding; with much education being administered only in English there, the author assumed that most participants would have a $75 \%$ level or even higher. Interestingly, $38 \%$ of participants felt they had a level 4 or high intermediate level of English in general.

\section{Conclusion}

Although the sample was small and the conditions imperfect, the author and research assistant were able to collect interesting and useful data in order to examine the socioeconomic and English situation in Kathmandu, Nepal. Spearman's R showed statistically significant correlations English level and income in both analyses. Although causation cannot be proved, it is very obvious and interesting that English ability is of utmost importance to those working in NETI in Kathmandu. English is offered as a base language in education there. Even so, in qualitative data many participants reported only a $50 \%$ level of English understanding in communication. Of the total, only $38 \%$ of participants felt they had a high intermediate command of English, a number that should be increased in the future. One way to help this total increase is to create more effective English programs for NETI employees in Kathmandu and surrounding areas. This will ensure that English will help young NETI employees receive both stable income and stable employment long into the future. 


\section{REFERENCES}

[1] Government of Nepal, Ministry of Culture, Tourism and Civil Aviation. (2014). Nepal Tourism Statisticts, 2014. Retrieved from http://www.tourism.gov.jp July 5, 2016.

[2] Kachru, B. (1985). Standards, codification, and sociolinguistic realism: The English language in the outer circle. In R. Quirk and H.G. Widdow son (Eds). English in the World: teaching and learning the languages and literatures, (pp.11-30). Cambridge: Cambridge University Press.

[3] Council of Europe. (2001). Common European Framework of Reference for Languages(CEFR).Retrieved from http://www.coe.int/t/dg4/linguistic/cadre_en.asp, March 30, 2010.

[4] Becker, Gary S. (1964). Human Capital. The University of Chicago Press.

[5] Mincer, Jacob. (1974). Schooling, Experience, and Earnings. Columbia University Press.

[6] Casale, D \& Posel, D. (2011). English Language Proficiency and Earnings in a Developing Country: The Case of South Africa. Journal of Socio-Economics, 40(4) 385-393.

[7] Bellante, D. \& Kogut, C. (1998). Language skills and US Labor Market Experience and the earnings of immigrants. Journal of Manpower, 19:5, 319-330.

[8] Kim, J. (2003). Education, English language proficiency, and earning of Male Immigrants in the US Labor Market. Jounral of business and economy research, Vol. 1, No. 3, 17-26.

[9] DiPaolo, A. \& Tansel, A. (2015). Returns to Foreign Language Skills in a Developing Country: The Case of Turkey. Journal of Development Studies, DOI:10.1080/00220388.2015.1019482

\section{APPENDIX}

\section{Nepal English Ability In Ecotourism Industry Questionnaire, March 4-6, 2016}

\section{Survey Number}

Type of Shop (souvenir shop, restaurant, guesthouse, tour guide, etc.)

1. i.Male ii.Female

2. How old are you?

2. Are you married? i.married ii.single iii.divorced iv.widowed

3. Do you have children? i.no ii.yes (if yes, how many?

4. What is your living situation? i.alone/with friend husband/wife/children iv.other (dormitory, etc.)

ii.with parents $\quad$ iii.with

5. What province are you from? (circle) i. ii. iii. iv. v. vi. vii.

What city are you from? (write)

6. What is your highest educational level? i.primary(6 years) ii.secondary( 9 years) iii.high school(12 years) iv.university (16 years)

v. Other (circle and write number of years)

7. Did you graduate from high school? i.yes ii.no

8. How many total years did you study English in school? you study English per week in school? hours.

9. What languages did you learn in school? (write all)

10. What languages can you speak now? (circle all) i.Nepali ii.English

iii. Hindi iv. Sherpa v. Japanese vi.Chinese vi.Thai

vii. other language(s) (circle and write all)

11. How long have you worked at this job? years months

12. Did you have a previous job? i.no ii.yes (if yes, write job type

13. What was you previous salary? (write US dollar amount) \$ per month 
14. How many hours per week do you work now? hours per week

15. What did you need to get this job? (for example: interview, written test, language skill, experience)

16. Did your English ability help you get a job? i. yes

ii. no

iii. not sure

17. Is your salary better with English proficiency?

i. yes ii. no

$$
\text { iii.not sure If yes, why? }
$$

18. Do you think you can get a better job with English in the future? i. yes

ii. no iii. not sure

19. What is your level of understanding and communication in ENGLISH ONLY? i.0\%
ii. $10 \%$ iii. $25 \%$
iv. $50 \%$
v. $75 \%$ vi. $100 \%$

20. Do you study English now? i.yes ii. no If yes, how? (teacher, school, books)

21. How do you use English at your job?

i. I can only use some English words

ii. I can say short sentences, but my English is very broken and I have a small vocabulary and little confidence

iii. I can explain with in more detail with more vocabulary, and I have some confidence

iv. I can explain a lot of things and have more confidence but I make mistakes

v. I can understand $100 \%$ and explain in detail fully with confidence

22. How often do English speakers visit your job?

i. every day ii.3 days per week iii. once per month iv. once per year

v. never

23. What do you think your own English level is? low intermediate iv. high intermediate

i. low beginner ii. high beginner

iii.

24 . What is your salary? $\$$ per month

$$
\text { Or, range i. (2,000-5,000 NPR)__ ii. (5,000-8,000NPR) }
$$

iii. $(8,000-11,000 \mathrm{NPR})$ iv. $(11,000-14,000 \mathrm{NPR})$ v. $(14,000-17,000 \mathrm{NPR})$

vi. $(17,000-20,000 \mathrm{NPR})$ vii. Over 20,000NPR

25 . How much money do you spend per month on rent, toiletries, etc? \$ per month

26. How much money do you spend on studying English per month? \$ per month

27. English assessment. (Interviewer: push record. Say the survey number from the top right corner of this paper to coordinate the questionnaire with the recording. Interview the person and speak with him or her for around five minutes in English)

What do you think this person's English communication ability is?

English ability level (write 0-5) 